\title{
Who Can't Raise Capital?: The Scylla and Charybdis of Capital Formation
}

\author{
James D. Cox
}

$\mathrm{F}$ IFTY years ago, the worst one could be called was a communist. Today, it likely is not flattering to be so referred to, but worse yet to be called a regulator. Regulators are found at all levels of government; one of the missions of government is, after all, to regulate for the greater good. But because opinions vary widely on just what is the "good" that is to be served, there is the Newtonian effect whereby each regulatory initiative produces an equal and opposite claim that harm, not good, is the end product of the regulator's initiative. So it has been for several decades with the arcane, but economically significant, area of securities regulations.

One can say with some credibility that securities transactions are among the most highly regulated in the economy. Not only do state and federal regulation of securities transactions coexist but also market intermediaries are further regulated by well-armed self-regulatory organizations. While the regulatory bodies share the common goal of investor protection, the Securities and Exchange Commission also has among its stated objectives the promotion of capital formation. ${ }^{2}$ Thus, it finds itself frequently faced with the conflicting tugs of investor needs and calls for less friction on capital formation and the operation of securities markets. ${ }^{3}$ And, most significantly, Congress has in recent years been attuned to the needs of business as the nation competes in an increasingly globalized marketplace. That is, today regulatory initiatives for securities markets occur within the red-hot crucible heated by growing concern that regulation increases capital costs for domestic firms and thereby places them at a profound disadvantage in an increasingly competitive global economy. ${ }^{4}$

But just where is the state regulator to be placed in this global economy? State blue sky laws long preceded the U.S. securities laws. Federal regulation

1 Brainerd Currie Professor of Law, Duke University. The author is grateful for the research assistance provided by Messrs. Robert Blaney and Alex Dominey.

2 See, e.g., Securities Act of $\mathrm{I}_{933} \S_{2}$ (b), I5 U.S.C. $\$ 77 \mathrm{~b}$ (2012) (mandating that in adopting rules the SEC consider, in addition to investor protection, "whether the action will promote efficiency, competition, and capital formation").

3 Luigi Zingales et al., Interim Report of the Committee on Capital Markets Regulation 67 (Nov. 30, 2006), available at http://www.capmktsreg.org/pdfs/rr.3oCommittee_ Interim_ReportREV 2.pdf.

4 See, e.g., id. at 59 (emphasizing the decline in capital formation that occurs in U.S. markets due to an inhospitable regulatory environment). 
was seen as necessary because of weaknesses in the state laws. Hence, the Securities Act of 1933 treated state and federal regulation of securities offerings as complementary, and they so operated for sixty years. The state regulation was hardly the mirror image of federal regulation. Whereas much of the U.S. securities laws are focused on disclosure, most state blue sky laws embraced both disclosure and merit review as ways to protect state investors. ${ }^{5}$ Armed with a statutory license to consider whether the offering was too risky or otherwise bore signs of opportunistic behavior by insiders, the states implemented disclosure and merit evaluation regulations, introducing levels of review unparalleled in the federal disclosure-only process.

A dramatic collision of state regulation and Congress's preference for capital formation occurred with the enactment of the National Securities Markets Improvement Act of $1996 ;^{6}$ the legislation would have occurred earlier had globalization been a concern earlier. ${ }^{7}$ A central feature of NSMIA is the preemption of state authority to regulate certain offerings of securities. ${ }^{8}$ NSMIA's preemption of state authority embodied negative views that ranged from the belief that state regulation was unnecessary in light of protections involved with the offering complying with federal standards to the highly negative view that state regulation was not only burdensome but also arbitrary. ${ }^{9}$

\section{The Stratification of U.S. Markets}

Much of the federal securities law is built upon the distinctions that separate investors into groups. Indeed, Table 1 reflects an important reality regarding capital formulation in the United States: most capital is not raised via offerings registered with the SEC, but instead through one of many exemptions, each of which is largely premised on various investor qualities that are specified in the exemption. ${ }^{10}$

5 See U.S. Sec. \& Exch. Comm'n, Report on the Uniformity of State Regulatory Requirements for Offerings of Securities that Are Not "Covered Securities" (Oct. II, 1997) [hereinafter SEC UnIformity RePORT], available at http://www.sec.gov/news/studies/ uniformy.htm (reporting that about forty states undertake some form of merit review as part of their permitting of offerings within their state).

6 National Securities Markets Improvement Act (NSMIA), Pub. L. No. 104-290, IIo Stat. 3416 (1996) (codified as amended in scattered sections of i5 U.S.C.).

7 See generally Jennifer J. Johnson, Private Placements: A Regulatory Black Hole, 35 DeL. J. Corp. L. 151, 166 (2010) (detailing the legislative history of the NSMIA).

8 Securities Act of 1933 § 18(a), I5 U.S.C. § 77r(a) (2012).

9 See SEC Uniformity Report, supra note 5.

10 See Vladimir Ivanov \& Scott Bauguess, Capital Raising in the U.S.: An Analysis of Unregistered Offerings Using the Regulation D Exemption, 2009-20i2, at 9 (July 20I3) [hereinafter Ivanov \& Bauguess Study], available at http://www.sec.gov/divisions/riskfin/ whitepapers/dera-unregistered-offerings-reg-d.pdf (reporting that, based on the data supporting Figure 4, registered offerings (debt and equity) in 2012 totaled \$I.2 trillion, whereas capital raised solely through the Rule 506 exemption was $\$ 898$ billion; adding in other exempt offerings boosts the total sum raised through exemptions considerably above \$1.2 trillion); see also Eliminating the 
Table 1. Aggregate capital raised in 2009-2012 by offering method (\$billions).

\begin{tabular}{|c|c|c|c|c|c|}
\hline $\begin{array}{c}\text { Year } \\
2009\end{array}$ & Public Debt & Public Equity & Reg D & Rule 144A & Reg S + Sec 4(a)(2) \\
\hline 2010 & 1,035 & 245 & 600 & 825 & 200 \\
2011 & 850 & 240 & 1.030 & 750 & 125 \\
\hline 2012 & 975 & 200 & 875 & 525 & 75 \\
\hline
\end{tabular}

At the top of the investor species is the qualified institutional buyer. This generally is an entity that manages a sizeable portfolio; for most entities the portfolio must be at least $\$ 100$ million dollars to earn the QIB designation. ${ }^{12}$ The SEC created the QIB distinction with the promulgation of Rule 144A, an offering safe harbor that allows syndications of certain securities with little regulation if the offering is limited to those meeting the rule's definition of a QIB.$^{13}$ As seen in Table 1, Rule $144 \mathrm{~A}$ syndications are a significant component of yearly capital formation in the United States.

Earlier, Congress authorized lighter regulation of securities that are offered only to accredited investors. ${ }^{14}$ The SEC has defined "accredited investor" broadly. To assure this concept could function and would be workable from an enforcement perspective, accredited investor was defined objectively, and included organization type, relation to the issuer, net worth, or income. ${ }^{15}$ Accredited investors thus form a distinct part of the capital market and vastly outnumber QIBs (certainly all QIBs qualify as accredited investors but

Prohibition Against General Solicitation and General Advertising in Rule 506 and Rule 44A Offerings, Securities Act Release No. 94I5, Exchange Act Release No. 69,959, 78 Fed. Reg. 44,77I, 44,793 fig.5 (July 24, 2013) (to be codified at I7 C.F.R. pts. 230, 239 \& 242) [hereinafter SEC Eliminating Advertising Release].

11 Ivanov \& Bauguess Study, supra note 9, at 4 . The authors of this revealing study, Messrs. Ivanov and Bauguess, observe that there is a likely underreporting bias of the amounts actually sold through small offerings due to a variety of factors, most notably that Regulation D filings can, and frequently are, made before the offering is completed; however, an amended filing is required if the amount sold is more than ten percent. Id.

12 The definition of a "qualified institutional buyer" (QIB) is set forth in paragraph (a)(I) of Rule I44A. See I7 C.F.R. $\$ 230 . I_{44} A(a)(I)$ (20I4). Banks face a further $\$ 25$ million net worth requirement, I7 C.F.R. $\S 230 . I_{44} \mathrm{~A}(\mathrm{a})(\mathrm{I})(\mathrm{vi})$, and dealers registered with the SEC face a lower portfolio threshold of $\$ 10$ million, I7 C.F.R. $§ 230$. I4 $\mathrm{A}(\mathrm{a})(\mathrm{I})$ (ii).

13 See I7 C.F.R. § 230.I44A(a)(I) (defining “qualified institutional buyer").

14 I5 U.S.C. $\$ 77 \mathrm{~d}(\mathrm{a})(5)$ (2012). The statutory exemption, however, has a ceiling of $\$ 5$ million. I5 U.S.C. $\$ 77 \mathrm{C}(\mathrm{b})(\mathrm{I})$ (20I2). The SEC nonetheless employed its rulemaking authority to incorporate the reasoning behind exempting offerings solely to accredited investors into its safe harbor Rule 506, I7 C.F.R. $\$ 230.506$ (2014), so that, subject to other conditions of the safe harbor, no monetary ceiling applies.

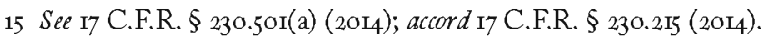


not vice versa). ${ }^{16}$ The overall rationale for little paternalism being accorded QIBs and accredited investors stems from the belief that they each possess endowments-wealth, experience, and intelligence-likely to enable them to self-protect against opportunistic behavior.

Demonstrated wealth, experience, and intelligence also characterize a third market for offerings: those affected by the authority of Section 4(a)(2)'s private offering exemption. ${ }^{17}$ Whereas both Rule 144A and the accredited investor are based solely on objectively verifiable criteria, the "sophisticated investor" criteria that underlies Section 4(a)(2) is not solely based on inputs that are so verifiable. ${ }^{18}$ Moreover, the Supreme Court's interpretation of the exemption interjected an information component that is not a prerequisite for either Rule 144A offerings or those made solely to accredited investors. ${ }^{19}$ As seen in Table 1, Section 4(a)(2) offerings (even augmented by offshore offerings made under Regulation S) are miniscule compared to Rule 144A offerings. ${ }^{20}$ Table 1 however, understates the significance of Section 4(a)(2) since Regulation D offerings include a substantial number of investors who fall within Section 4(a)(2); indeed, ninety-nine percent of Regulation D offerings are pursuant to SEC Rule 506, the safe harbor for Section 4(a)(2) ${ }^{21}$

The residual, the great unwashed, category of investors are rightly seen as those having the greatest need for paternalism. They lack either objective or subjective qualities that suggest they can "fend for themselves." 22 Because of a decision made years ago that issuers, not investors, would be regulated, public resources are now devoted to the protection of this group of investors. ${ }^{23}$

16 The SEC recently estimated that at least 8.7 million households, or about $7.4 \%$ of all U.S. households, qualified as accredited investors in 2010. SEC Eliminating Advertising Release, Securities Act Release No. 9415, Exchange Act Release No. 69,959, 78 Fed. Reg. 44,771, 44,793 (July 24, 2013) (to be codified at I7 C.F.R. pts. 230, 239 \& 242) (citing Survey of Consumer Finances: Survey Data, BD. Governors Fed. Res. Sys., available at http://www.federalreserve.gov/econresdata/scf/ scf_2orosurvey.htm (last updated Apr. 16, 2013)).

17 Securities Act of 1933 \$ $4(\mathrm{a}),{ }_{5}$ U.S.C. $\$ 77 \mathrm{~d}(\mathrm{a})(2)$ (2012) ("[T] this title shall not apply to ... transactions by an issuer not involving a public offering.").

18 Scherk v. Alberto-Culver Co., 4I7 U.S. 506, 526 (I974) (Douglas, J., dissenting) ("The Act does not speak in terms of 'sophisticated' as opposed to 'unsophisticated' people dealing in securities. The rules when the giants play are the same as when the pygmies enter the market.").

19 SEC v. Ralston Purina Co., 346 U.S. II9, I24-25 (I953). Although Justice Clark's opinion never expressly refers to sophistication, later decisions have held, with some uniformity, that Clark's formulation that the exemption exists for those who can "fend for themselves" necessarily meant that each offeree had, by experience or education, financial sophistication. See James D. Cox, Robert W. Hillman \& Donald C. Langevoort, Securities Regulation: Cases and Materials 267-7i (7th ed. 20I3).

20 Ivanov \& Bauguess Study, supra note 9, at 9.

21 Id. at 7,9 .

22 This glib expression flows from Ralston Purina Co., 346 U.S. at $124-25$, and embodies the overall philosophy of the private offering exemption.

23 Professor Choi developed an intriguing model to show how markets might be segmented according to investor quality. Stephen Choi, Regulating Investors Not Issuers: A Market-Based 
Regulation has, until recently, greatly limited this group of investors' access to new offerings. The irony of this regulatory choice is that investors who fall into this group are permitted to purchase, with abandon, securities sold on public markets, including the unregulated Pink Sheet Market where issuers that do not comply with SEC reporting requirements trade. They are not, however, permitted to acquire unregistered securities offered by the issuer. Thus, their protection depends not on what they purchase, but the medium with which they pursue the investment.

The duplicity with which the federal securities laws treat unsophisticated, non-accredited investors was not lost on Congress. Among the justifications for the crowdfunding provision ${ }^{24}$ that Congress enacted with the JOBS Act of $2012^{25}$ was the egalitarian belief that opportunities to invest in the next Apple should not be limited to QIBs and accredited investors. It is perhaps more soundly argued that regulation should somehow complement the reality that most small venture entrepreneurs know few-if any - sophisticated, accredited, or QIB investors so that an exemption in addition to this elite group is necessary. That is, regulation premised on the above categories forecloses the budding entrepreneur from sources of capital that would be the most likely first approach by the entrepreneur. To be sure, relief from the federal regulation is available to the small entrepreneur who raises capital only locally. The federal securities laws exempt offers made exclusively to the residents of the same state of the business's formation and principal place of business. ${ }^{26}$ But, as will be seen, regulation at the state level more than fills this void, except in very limited offerings.

\section{The World After NSMIA}

Blue sky regulation has long been a punching bag for those seeking answers to why small enterprises face formidable challenges when raising capital. This is criticism for which state regulators need not, in today's markets, necessarily be apologetic. An understanding of this statement begins with the NSMIA. That Act, in addition to preempting state authority with respect to SEC registered offerings of securities listed, or securities that will be listed on a national securities exchange, also provided that private offerings were preempted. ${ }^{27}$ In combination, this meant that the permitting realm of blue sky

\footnotetext{
Proposal, 88 Calif. L. Rev. 279, 280 (2000).

24 See Securities Act of $1933 \S \S 4(\mathrm{a})(6), 4$ A, I5 U.S.C. $\S \S 77 \mathrm{~d}(\mathrm{a})(6), 77 \mathrm{~d}-\mathrm{I}(20 \mathrm{I} 2)$; see also id. $\S$ 5,15 U.S.C. $\$ 77 \mathrm{e}$.

25 Jumpstart Our Business Startups (JOBS) Act, Pub. L. No. II2-106, I26 Stat. 306 (20I2) (codified as amended in scattered sections of 15 U.S.C.).

26 These exemptions are described in 15 U.S.C. $\$ 77 \mathrm{c}(\mathrm{a})(\mathrm{II})$ and its accompanying safe harbor rule, 17 C.F.R. § 230.147 (2014).

27 See NSMIA, Pub. L. No. 104-290, iro Stat. 3416 (1996) (codified as amended at i5 U.S.C. $\S 77 \mathrm{r}(\mathrm{b})(4)(\mathrm{E})(2 \mathrm{OI2}))$.
} 
laws extended to what was left-non-registered offerings that were not made to accredited or sophisticated investors. The mission of the blue sky regulator was essentially that of protecting proverbial widows, widowers, and orphans. Moreover, consider that registered offerings are by larger companies, more seasoned than those whose capital formation must occur within the shadows of federal exemptions, such as the intrastate exemption, or those where the issuer is targeting a smaller sum than could be economically registered with the SEC. Smaller issuers not only present greater risks but also have less financial slack to withstand economic shocks, frequently depend on a single product, and are largely local-as seen above, their investors are neither QIBs, accredited, sophisticated, nor protected by multiple certification forces that surround the public offering. This naturally causes the blue sky regulator angst and response that this bottom-tier of investors need protection. This response finds salience in statistics that identify fraud in non-public offerings as the leading focus of blue sky law enforcement. ${ }^{28}$ It is therefore myopic to overlook the reality that offerings not preempted by NSMIA are a fertile area for fraudsters to sow their schemes. At the same time, small businesses exist, they need capital, and it is an understatement that most of their promoters are not fraudsters but businesses eager for capital.

Champions of crowdfunding had reason to believe that crowdfunding could be the salvation for capital formation for such small businesses. There is a good deal of appeal to the image of empowering entrepreneurs to use the ubiquity of the Internet to connect entrepreneurs and small investors. This author believes that crowdfunding, as an idea, is quixotic. Worse, the burdens incident to accessing the exemption are so burdensome that it will likely become the last resort for legitimate enterprises to raise capital.

The romantic image that surrounds crowdfunding is that members of the hardworking middle class can invest in ventures that will thrive, growing over time so that the crowdfunding investors will cease to be middle class. This warm image overlooks that, if this metamorphosis of the startup is to occur, it will be through several rounds of financing. Significantly, the subsequent rounds of financing will involve organized, sophisticated, and experienced investors, namely angel investors and venture capitalists, whose participation will necessarily mean a good deal of dilution to the earlier investors.

Angels and early round venture capitalists have always faced this risk; they address the ever-present threat of dilution contractually securing rights that effectively make up for dilution when they believe a subsequent round of financing will advance everyone's interest. In contrast, the participants in crowdfunding cannot be expected to be sophisticated, or to have sufficient investment at stake to merit professional representation, and are so dispersed as to encounter non-trivial costs to engage in coordinated response. Moreover,

28 See U.S. Gov't Accountability Office, GAO-I2-839, Securities Regulation: Factors that May Affect Trends in Regulation A Offerings 8 (20I2) [hereinafter GAO REPORT]. 
these same features likely will cause crowdfunding investors to engage in contractual protections before they make their investments.

Not all the problems with crowdfunding fall on the investors. The crowdfunding provision demands annual reporting by the issuer, something not required by any other federal exemption. ${ }^{29}$ It also requires efforts to ascertain whether the crowdfunding investor has exceeded the ceiling that an individual can invest through crowdfunding offerings and imposes a liability standard for any material misrepresentation in connection with the offering. ${ }^{30}$ Thus, even when the final crowdfunding rules are adopted, we likely will find very limited experience on this provision, especially if small issuers can raise funds through other exemptions.

Regulation A provides fewer regulatory burdens than crowdfunding. Exercising its rulemaking authority under Section 3(b), the SEC created an abbreviated form of regulation in Regulation $A .{ }^{31}$ Unlike other federal exemptions, Regulation A offerings are not restricted to certain types of offerees or purchasers; hence, a Regulation A offering can be broadly and aggressively promoted. Furthermore, there are no resale restrictions, so the issuer does not experience the liquidity discount that prevails when offers are made under other exemptions. Nonetheless, the Government Accountability Office famously reported the effective demise of this exemption, persuasively suggesting its disuse was the function of several of factors. ${ }^{32}$ Among the culprits identified were that Regulation A offerings remain subject to the blue sky permitting authority and the so-called abbreviated disclosure nonetheless was not light enough to justify the costs because the exemption had a twelve-month ceiling of $\$ 5$ million. ${ }^{33}$ The ultimate death of the traditional Regulation A was NSMIA; with Section 4(a)(2)-based offerings removed from the heavy hand of the Blue Sky regulator, the benefits of private placements overwhelmed those associated with Regulation A offerings. ${ }^{34}$

A recent SEC study of Regulation D offerings illuminates the significance of NSMIA on issuer choice. ${ }^{35}$ While Regulation D sets forth three distinct issuer safe harbors, only one of them, Rule 506, is based on Section 4(a)(2) and hence qualifies offered securities as "covered securities" for which state regulation is preempted. ${ }^{36}$ In broad overview, Rule 506 permits the issuer to

29 I5 U.S.C. $\$ 77 \mathrm{~d}-\mathrm{I}(\mathrm{b})(4)$ (2OI2).

$30 \quad I d$. $\S 77 \mathrm{~d}-\mathrm{I}(\mathrm{c})$.

31 Regulation A, I7 C.F.R. §§ 230.25I-263 (2014).

32 GAO Report, supra note 26 , at $\mathrm{I} 6$.

33 Id. at I6-I9. The burdensome review process for both SEC and state administrators under Regulation $\mathrm{A}$ is a process exacerbated by the fragmented state law standards that must be met. In contrast, there are procedural advantages to using Regulation D, since it is usually quicker and less expensive. $I d$.

34 See id. at 9; see also GAO Report, supra note 26, at 9.

35 Ivanov \& Bauguess Study, supra note 9.

36 Securities Act of 1933 § I8(b)(4)(E), I5 U.S.C. $\$ 77 \mathrm{r}(\mathrm{b})\left({ }_{4}\right)(\mathrm{E})(2 \mathrm{OI2})$. 
sell unlimited dollar amounts of securities without registration to an unlimited number of accredited investors and up to thirty-five non-accredited investors. ${ }^{37}$ Recently, exercising authority provided by the JOBS Act, the SEC declared that Rule 506 offerings could involve general advertisement and solicitation to accredited investors. ${ }^{38}$ This development adds immensely to the overall attractiveness of Rule 506. Indeed, Rule 506 must be seen as the giant tree that smothers growth of other varieties of the exemption species. ${ }^{39}$ Consider that the safe harbor created in Rule 506 dwarfs that of the other two safe harbors; $94 \%$ of Regulation D offerings by number, and $99 \%$ by dollar amount, occur under Rule $506 .{ }^{40}$ The significance of Rule 506 is enhanced by noting that the amount of new capital raised pursuant to private offerings in 2012 totaled $\$ 1.7$ trillion, compared to $\$ 1.2$ trillion in new capital raised through registered offerings; ${ }^{41}$ recall that in the exemption arena Rule 506 is the dominant exemption. Moreover, approximately two-thirds of the Regulation D offerings represent new equity. ${ }^{42}$ Of particular importance to this article is that the median amount of Regulation D offerings (recall that, by number, $94 \%$ are Rule 506 offerings) is $\$ 1.5$ million. ${ }^{43}$ Notably, issuers routinely prefer Rule 506 to the other Regulation D safe harbor exemptions for which they could qualify; for example, the offering could fall within Rule 504, which has much fewer qualifications than Rule 506. ${ }^{44}$ The conclusion to be drawn from this preference is that the state law preemption that Rule 506 offerings enjoy matters a good deal to issuers and contributes to how capital formation occurs in the United States. Equally important is that among non-financial issuers (e.g., startups and other small businesses) a non-accredited investor participated in only $11 \%$

37 I7 C.F.R. $\$ 230.506(a)-(c)(i)(2014)$.

38 i7 C.F.R. § $230.506(\mathrm{c})$.

39 See e.g., GAO Report, supra note 26 , at I9 (identifying the lower burdens of Rule 506 as a cause for disuse of Regulation A).

40 Ivanov \& Bauguess Study, supra note 9, at $7 \& 7$ fig.3.

41 Id. at 8,9 fig. 4 .

42 Id. at 9, Io fig.5, 9 tbl.2 (noting Table 2's figure of two-thirds of 3I,47I which shows that while public offerings of debt and even Rule I44A syndications are larger in absolute terms, most debt offerings involve "rolling over" existing debt so that they do not involve new infusions of funds into business).

43 Id. at 4 .

44 In addition to requiring each purchaser be accredited, sophisticated, or have a purchaser representative, Rule 506 imposes disclosure requirements to non-accredited investors, as well as other information requirements, such as what information has been provided accredited investors and restrictions on resale. Offerings pursuant to Rule 504, although limited to \$I million, are nonetheless conditioned on compliance with state law permits or exemptions, provided that the permit or exemption compels disclosure. I7 C.F.R. $§ 230.504(\mathrm{~b})(\mathrm{I})(\mathrm{i})-(\mathrm{ii})$ (2014). Such disclosure is not a condition for Rule 504 if the offering is pursuant to a state law exemption conditioned on sales being made exclusively to accredited investors. See id. $\S 230.504(b)(1)(i i i)$. Rule 506 also does not require disclosure for sales made to accredited investors. Id. Nonetheless, it would be rare that an issuer would prefer Rule 504 to 506, even if sales were to be made only to accredited investors, since with Rule 506 the issuer has the opportunity to raise more than \$I million. 
of the offerings. ${ }^{45}$ Thus, accredited investors are the dominant providers of new capital for new businesses. And the number of investors in those offerings is quite small: the mean number of investors is eight for Regulation D offerings by non-financial issuers (median of four). ${ }^{46}$

So, what can we surmise from the above data? We see that a good deal of capital formation by small enterprises not only can occur but also does occur through Rule 506 and thus is outside the permitting authority of the states. For non-financial issuers, the average number of purchasers is quite small, eight, and the overwhelming percentage of the purchasers are accredited investors. ${ }^{47}$ Minimally, this data underscores the earlier observation that the wards of the Blue Sky regulator are the residual category of investors-those who are not QIBs, accredited, or sophisticated. They truly are a species needing some paternalism. Even for this group, as examined in the next section, there may well not be much protection due to the availability of state exemptions from the blue sky laws.

\section{What Is the Problem with State LaW Exemptions?}

Offerings that are not preempted by NSMIA may nonetheless escape review by the state administrator. All states provide a range of offering exemptions. The exemption provided by Massachusetts is representative of the genre across the states. Under the Massachusetts provision, no permit need be acquired from the state administrator if the offering within a twelve-month period does not exceed twenty-five persons and sales are made to no more than ten in-state persons. ${ }^{48}$ By way of further illustration of the contours of this type of exemption, Texas is fifty percent more generous than Massachusetts, as it allows sales to fifteen investors during a twelve-month period. ${ }^{49}$ States like Illinois provide an exemption for up to thirty-five purchasers, provided the offering is not more than $\$ 1$ million. ${ }^{50}$ Massachusetts is typical of other states in that an exemption is conditioned on there being no general solicitation or advertisement. $^{51}$

45 Ivanov \& Bauguess Study, supra note 9 , at 15 tbl. 4.

$46 \mathrm{Id}$.

47 Id. (reporting that only ten percent of the Regulation $\mathrm{D}$ offerings by non-financial issuers had participation by at least one non-accredited investor).

48 Mass. Gen. Laws Ann. ch. IIOA, § 402(b)(9) (West). Massachusetts, like many other states, has also adopted the so-called Uniform Limited Offering Exemption, which is designed to coordinate state and federal exemptions so that compliance with exemptions created in either Rule 505 or 506 of Regulation D would be similarly exempt from state regulation. Id. § 402(b)(9). An important limitation on the ULOE is the limitation on commissions to persons other than registered broker-dealers or their agents, as well as suitability requirements. Id.

49 Tex. Rev. Civ. Stat. Ann. art. 58I-5, § (I)(c) (West 20io).

508 i5 Ill. Comp. Stat. Ann. 5/4(G)(I)(a) (2008).

51 See 950 Mass. Code Regs. 14.402(B)(9)(e) (2014). 
It is ironic, if not paradoxical, that the hotbed of entrepreneurism, and one of the most resilient economies during the financial crisis, California, is among the most restrictive states in the scope of its exemptions. California limits the exemption to thirty-five persons (including those outside of California) and bars general solicitation and advertisements in connection with the offering. ${ }^{52}$ What makes this California exemption restrictive is that each of the purchasers either must enjoy a personal relationship with the issuer or be reasonably assumed to have the capacity to protect his own interest in the transaction. ${ }^{53}$ Thus, unlike Massachusetts or Texas, the exemption does not afford a means for the issuer to distribute any part of its offering to the residual class of investors. Relaxation of this requirement, however, is available for issuers who, after the offering, will have only a single class of voting common stock that is owned beneficially by no more than thirty-five persons. ${ }^{54}$ There is a further limitation in connection with the offering in that the issuer cannot pay for the offering's promotion. ${ }^{55}$

Superficially, the problem many small issuers must confront when raising funds outside the preemptive scope of NSMIA is that they cannot broadly canvas potential investors who are not accredited. A further practical constraint is that, even if they could approach a sizable number of potential offerees, the amount that each offeree could be expected to invest would be small. This, in combination with the state-imposed numerical limit on the number of purchases, means that the issuer will be unable to raise the funds it needs. Not to be overlooked in this explanation is the earlier reviewed data reflecting that there are very few investors on average in the small Regulation D offerings. ${ }^{56}$ Their success therefore depends on a few of the purchasers making a substantial investment. This in turn is reflected in the data that shows that very few Regulation D offerings have non-accredited purchasers. ${ }^{57}$

Thus, enterprises seeking capital that cannot proceed through the Rule 506 , because the likely purchasers either lack a high net worth or are not sophisticated investors, are forced to confront the state and its exemptions. The state exemption, in turn, requires that sales not exceed a very small number. Thus, like Scylla and Charybdis, the interaction of federal and state laws lead to a painful reality. It is likely not possible that the issuer can raise the needed funds within the state-imposed numerical limit on the number of purchasers. This conclusion flows from the following: After all, the contemplated pool of offerees, and hence the pool of likely purchasers that are available the issuer

52 Cal. Corp. Code $§ 25 \mathrm{IO} 2(\mathrm{f})(\mathrm{I}),(4)$ (West 2006 \& Supp. 20I4).

$53 \mathrm{Id}$. $\S 25 \mathrm{IO} 2(\mathrm{f})(2)$. Of interest is that a qualifying relationship does not necessarily include the employer-employee, security holder of the issuer, or customer of the issuer. CAL. Code REgs. tit. IO, § 260.IO2.I2(d) (2OI4).

54 Cal. Corp. Code $\S 25102(\mathrm{~h})$.

55 Id. $\S 25102(\mathrm{~h})(3)$.

56 See Ivanov \& Bauguess, supra note 9 , at 4.

57 See id. 
will not have the income, wealth or sophistication of the type that qualified the offering under Rule 506; it is this fact that prompts the issuer to resort to an exemption under the state law because had the offering qualified under Rule 506 the offering would have been exempt from state regulation. Thus, individuals within the pool of investors that the issuer must approach will be individuals of modest means. This means they can be expected to have small amounts to invest in the offering so that the issuer to raise the capital it desperately needs must approach a large number of such investors. This number can be expected to exceed the small number set forth in the state exemption.

Note that the source of the issuer's dilemma flows from it not having access to accredited or sophisticated investors. We do not know what enables some issuers to attract the interest of accredited investors that others cannot. It is very likely that this factor, not the narrowness of the state law exemption, explains which offerings slip outside the protective waters of Rule 506 and, therefore, face the strong winds of merit review. Simply put, the issuers that confront this capital formation dilemma do not know, and lack a viable means to connect with, accredited investors or sophisticated investors. ${ }^{58}$ Thus, these issuers are left with unsophisticated potential purchasers who presumably lack sufficient means or willingness to invest sufficient sums to enable the issuer to accomplish its objective within the thirty-five non-accredited purchaser limit. The problem is actually greater than described above. Rule 506 offerings are conditioned on there being no general solicitation or advertisement of the offering. This requirement mandates that the issuer or its representative have a preexisting relationship with the offeree, even though the offeree is otherwise sophisticated. ${ }^{59} \mathrm{~A}$ recent amendment to Rule 506 relaxes this prohibition when the issuer reasonably believes the approached investor is accredited.$^{60}$ Thus, a budding business may have some awareness that certain individuals are sophisticated and experienced investors, but not whether the individual meets the definition of being also accredited. As a result, issuers, who must confront the limited exemptions of state law, do so not just because they know only unsophisticated investors, but also because they lack a sufficient relationship with sophisticated investors to overcome the bar to general solicitations or to have a reasonable basis to believe they are accredited.

Crowdfunding may well be the antidote for the issuer's inability to connect to accredited investors. While this exemption does have a low dollar limit

58 See Rutheford B. Campbell,Jr., Regulation A: Small Businesses'Search for "A Moderate Capital," 3I Del. J. Corp. L. 77, 88 (2006) ("The problems for small businesses are . . . the difficulties they face in identifying potential investors and the costs of connecting themselves with the investors' demand.").

59 See generally Cox, Hillman \& Langevoort, supra note $\mathrm{I} 7$, at 29I (referencing the SEC no-action letter practice and emphasizing the importance of a preexisting relationship between the issuer (or those acting on its behalf) and offerees).

6o SEC Eliminating Advertising Release, Securities Act Release No. 9415, Exchange Act Release No. 69,959, 78 Fed. Reg. 44,77I, 44,77I (July 24, 2013) (to be codified at I7 C.F.R. pts. 230, 239 \& 242). 
for the offering, ${ }^{61}$ there is no limit on the number of purchasers. In addition, crowdfunding is among the offerings that fall within the definition of covered securities so that state regulation is preempted..$^{62}$ But as seen, crowdfunding has its costs, which will likely limit its practical use. However, the next section develops a very different approach that could prove very useful to many small enterprises.

\section{Capital Formation Through Intermediation}

The market intermediary has long been an essential link in capital formation. ${ }^{63}$ Simply stated, market professionals provide professional experience in matching ventures and investors; their credibility with investors flows not from their experience but by their being repeat players so that reputation is a predominant feature of their continued success. To be noted here is that crowdfunding portals are not served in this role in the same way since they are foreclosed from providing a recommendation. It remains to be seen whether such portals will morph, as did the early exchanges, into themselves as reputation intermediaries by imposing demanding criteria for securities offered through a sponsoring portal.

The SEC's new general solicitation provision provides some important assistance to small issuers. Rule 506 offerings can now include solicitations to accredited investors with whom the issuer or its representative does not have any preexisting relationship. ${ }^{64}$ There are, of course, important restrictions on this process with a common theme that there be a reasonable belief the solicited party is accredited. But the surmise above is that the challenge for small issuers, who in the past have sought capital outside Rule 506, is not solely that they lacked a preexisting relationship with accredited investors and others; they face an even more daunting challenge, namely that they likely are not attractive or attractive to enough investors to meet their financing goal. That is, for many issuers, it is not the requirement of a preexisting relationship with offerees that forces issuers out of Rule 506 and into the state permitting process. Their problem is they are simply not so attractive that funds can be raised from a small enough group so that not only must the approach be broadly based, thus constituting a general solicitation that removes them from Rule 506, but also they must appeal to a larger number than the state law exemption permits. On the other hand, the data supports the view that capital formation at low

61 Securities Act of $\mathrm{I}_{933} \S_{4}(\mathrm{a})(6)(\mathrm{A})$, I5 U.S.C. $\$ 77 \mathrm{~d}(\mathrm{a})(6)(\mathrm{A})(2 \mathrm{II2})$.

$62 I d . \S 18(\mathrm{~b})(4)(\mathrm{C}), 15$ U.S.C. $\S 77 \mathrm{r}(\mathrm{b})(4)(\mathrm{C})$.

63 See Ronald J. Gilson \& Reinier H. Kraakman, The Mechanisms of Market Efficiency, 70 VA. L. REv. 549, 6I6-I9 (1984) (showing investment bankers as intermediaries); Donald C. Langevoort, Angels on the Internet: The Elusive Promise of "Technological Disintermediation" for Unregistered Offerings of Securities, 2 J. Small \& Emerging Bus. L. I, 2-3 (1998) (illustrating the use of the Internet as an intermediary).

64 See 17 C.F.R. $\$ 230.506(b)(2)(i i)(2014)$. 
levels does occur and, as seen earlier, relies heavily on a small number of accredited investors. Thus, between 2009 and 2012, 19,424 offerings raising less than $\$ 1$ million were made by non-fund issuers pursuant to Rule 506 , and 2702 offers were made under either Rule 504 or $505 . .^{65}$ Thus, about one in eight issuers invoking Regulation D cannot raise their capital without reaching out to non-accredited and non-sophisticated investors. ${ }^{66}$ For this group of issuers, the recent relaxation of solicitations for Rule 506 offerings will not likely change their fate.

Another approach for issuers that lack appeal to accredited investors, or even sophisticated investors, is to invoke the services of an intermediary. To some extent, this practice already exists within Rule 506. Broker-dealers that have a stable of clients can, under Rule 506, satisfy the necessary connection to avoid prohibited general solicitation of, or advertisement to their existing clients. An SEC study found that only 13\% of Regulation D offerings below $\$ 1$ million during the study period (2009-2012) utilized the services of a broker. ${ }^{67}$ Importantly, brokers can provide assistance beyond just connecting issuers with a stable of potential investors. Regulation D sets forth procedures for a broker, or others, to act as a purchaser representative for unsophisticated purchasers and thereby satisfy a central requirement of Rule $506 .{ }^{68}$ Thus, a mechanism exists whereby broker-dealers could become important intermediaries between investors and small firms seeking capital. We therefore see that Rule 506 provides a medium by which small issuers who are isolated from investors not only locate and communicate their offering to investors without running afoul of the bar to general solicitations but also provides a means for the broker to address any want of sophistication on the part of any offeree. The remaining hurdle facing the issuer is whether investors are persuaded that the investment's expected return is commensurate with the significant risk of the security offered for sale.

Indeed, the risk-return calculus is likely the source of the capital hungry issuer's greatest challenge. Any intermediation provided between issuer and investor qualifies the intermediary as a broker. ${ }^{69}$ This invites a host of regulatory burdens. In the context of this topic, the most significant of those duties is the suitability requirement. In 2010, this duty was recast and strengthened in

65 Ivanov \& Bauguess, supra note 9, at 8 tbl.2.

66 Among non-financial issuers invoking Regulation D in 20I2, only Io\% of the offerings included at least one non-accredited investor. Id. at 15 tbl. 4 .

67 Id. at I7 \& I7 fig.II; Jennifer J. Johnson, Private Placements: Will FINRA Sink in the Sea Change?, 8I U. CIN. L. Rev. (forthcoming 20I3) (manuscript at 25 n.9I), available at http://papers. ssrn.com/sol $3 /$ papers.cfm?abstract_id=2294I42 (collecting results of various other studies).

68 I7 C.F.R. $\$ 230.506$ (c) (20I4).

69 "Broker" is broadly defined. See Securities Exchange Act of 1934 § 3(a)(4), I5 U.S.C. § $78 \mathrm{c}(\mathrm{a})(4)(2 \mathrm{OI})$ (“' $[\mathrm{B}]$ roker' means any person engaged in the business of effecting transactions in securities for the account of others."). 
Financial Industry Regulatory Authority (FINRA) Rule $2111 .{ }^{70}$ Broadly stated, Rule 2111 embodies the suitability obligation of the broker as the courts, SEC, and FINRA have interpreted that duty over the years. Rule 2111 requires that the broker must first investigate whether the security is suitable for any investor. ${ }^{71}$ Next, the broker must find that the security is suitable for his particular client. ${ }^{72}$ Under the first prong, the broker has an affirmative due diligence obligation to investigate the issuer and its business. This carries forward the case law requirements that brokers "know their security." 73 The second requirement entails the traditional customer-focused factors; at its core this assessment focuses on the customer's tolerance to risk given such factors as his financial situation, portfolio, and objectives. Thus, we can see how brokers, even though meeting the conditions to be a purchaser representative, nonetheless cannot recommend the security to the represented customer because the security is not suitable for the customer. Most significantly, it is difficult to believe that investing in a small business, and particularly one with little operating history and little liquidity for its shares, is appropriate for the investor who is neither accredited nor sophisticated. To be sure, there are third-party vendors who for a fee provide due diligence in connection with such offerings. ${ }^{74}$ But third parties do not change the inherent endowments of the investor that limit the range of suitable investments. Thus, the expected variance in returns are such that suitability standards commonly applied to brokers are unlikely to be met by investors whose endowments take them outside the accredited investor category.

To some extent, the attraction of crowdfunding is disconnecting the suitability determinations from the offering process. Portal operators are regulated, but their regulation is not focused on tailoring offerings to the endowments of their customers. Customers, therefore, drive the system. As a result, the governor on the process is not suitability but the dollar limits each customer may invest during a twelve-month period. However, as will be seen, those burdens likely are more manageable and of a lower order than the costs incident to crowdfunding. Among the burdens incident such intermediation is the suitability requirement that binds a broker not to recommend securities

70 Self-Regulatory Organizations, Securities Act Release No. 34-63325, Exchange Act Release No. 62718, 75 Fed. Reg. 71,479-85 (proposed Nov. 23, 2010).

71 FINRA, Rule 2III, Fin. Industry Reg. Auth, available at http://finra.complinet.com/en/ display/display_main.html?rbid=2403\&element_id=9859 (last visited Apr. 6, 2014) (describing how to determine the suitability of a security for a customer).

$72 I d$.

73 See, e.g., Hanly v. SEC, 415 F.2d 589, 595-96 (2d Cir. 1969) (“[A] salesman cannot deliberately ignore that which he has a duty to know and recklessly state facts about matters of which he is ignorant. He must analyze sales literature and must not blindly accept recommendations made therein.").

74 One such vendor is CrowdCheck, which provides not only due diligence, but also extensive information made available to subscribers via the Internet regarding small issuers. About Us, CrowdCheck, http://www.crowdcheck.com/about-us (last visited Apr. 6, 20I4). 
whose risks are inappropriate for the customer. Interjecting the broker between the crowdfunding portal and the customer resurrects the suitability requirement and robs crowd funding of a central benefit for starving issuers.

\section{Conclusion}

More capital is raised today through exemptions than through offerings registered with the SEC. This development is reassuring to those who fear regulation is choking the flow of capital to business and has thereby stunted job creation. On closer analysis, the data reviewed here does not provide that reassurance. When judged by offering amounts, most capital formation through federal exemptions is by large issuers; although small issuers do raise small amounts through federal exemptions. Data is reassuring-each year there are thousands of offerings raising about $\$ 1$ million that are made to a dozen or fewer investors. We might well expect these numbers will grow with the newly adopted solicitation rules that allow issuers and their representatives to troll for accredited investors.

Despite reassuring data supporting utilization of Regulation D, other restrictions continue. While the narrowness of state exemptions are of significant concern, we might wonder whether focusing on them ignores the real problem-the suitability determination brokers must satisfy. It is difficult to imagine that there are very many investment opportunities in small businesses that a broker believes to be suitable for her non-accredited investor client. To be sure, that client can instruct a broker to acquire an equally risky stock on the Pink Sheet market without the broker having to make a suitability determination. This is because, absent a recommendation, the broker is not required to satisfy the suitability rule. But, for the reasons developed above, many, if not most, capital hungry small issuers appear to know too few potential investors and intermediation is not just desirable, but necessary. For this group of issuers, the suitability requirements, not state exemptions as such, drive them to the medium of last resort, crowdfunding, where, as others have correctly reported, statutory and regulatory requirements provide a daunting path to raising capital.

Notwithstanding the presence of narrow state law exemptions, demanding suitability requirements, and a likely dysfunctional crowdfunding provision, we can believe that the right balance for the economy has been struck. The broad canvassing of accredited investors that is now permitted and the greater ease with which brokers are able to meet the suitability requirement for that class of investors provide an avenue that also skirts the demands of state regulation. What remains to be regulated are a subset of investors for whom the paternalistic protection of the securities laws, state and federal, is most compelling. Thus, if the innervated captain of a startup does face a regulatory Scylla and Charybdis, the havoc they each may visit is founded on investor protection and not arbitrariness on the part of the regulator. 
